\title{
Penerapan Patient Safety Pre-Post Partum di Pelayanan Kesehatan RS X di Kota Makassar
}

\section{The Implementation of Patient Safety Pre-Post Partum at X Hospital Health Services in Makassar City}

\author{
Nurmiati Muchlis ${ }^{1}$, Nasrudin ${ }^{2}$, Tutik Agustini ${ }^{3}$, Samsualam $^{3}$ \\ ${ }^{1}$ Faculty of Public Health, Universitas Muslim Indonesia, Indonesia \\ ${ }^{2}$ Faculty of Medical, Universitas Muslim Indonesia, Indonesia \\ ${ }^{3}$ Faculty of Nursing, Universitas Muslim Indonesia, Indonesia \\ Email: nurmiati.muchlis@umi.ac.id;ernase@yahoo.co.id; \\ tutik_agustini@yahoo.com;samsualamalam@yahoo.com
}

\begin{abstract}
ABSTRAK
Kualitas pelayanan kesehatan dapat menentukan kualitas derajat kesehatan masyarakat. Faktanya, masih terdapat masalah rendahnya kualitas pelayanan yang berdampak pada kesakitan, kecacatan bahkan kematian pada pasien. Penelitian ini bertujuan menggambarkan model penerapan patient safety pre-post partum di RS X Kota Makassar. Informan adalah seluruh petugas kesehatan (bidan, dokter, perawat) yang terlibat dalam penerapan patient safety pre-post partum pada masing-masing tingkat pelayanan kesehatan. Informan kunci yaitu penanggung jawab pelaksanaan pre-post partum pada masing-masing tingkat pelayanan kesehatan. Jenis penelitian ini evaluatif dengan pendekatan deskriptif. Lokasi penelitan dilakukan di Kota Makassar dan jangka waktu penelitian selama 6 (enam bulan). Hasil penelitian menunjukkan bahwa skoring penerapan patient safety RS X pada assesment risiko memperoleh nilai 4,0 identifikasi dan manajemen risiko terhadap pasien memperoleh nilai 3,7. Pelaporan dan analisis insiden memperoleh nilai 3,3, Kemampuan untuk belajar dan menindaklanjuti insiden 2 dan penerapan solusi untuk mengurangi serta meminimalisir risiko memproleh nilai 3,7. Rata-rata skor untuk semua dimensi sebesar 4,0 sedangkan total skoring sebesar 60 . Diharapkan manajemen rumah sakit membenahi penerapan patient safety, khususnya pada dimensi kemampuan belajar dan menindaklanjuti insiden.
\end{abstract}

Kata Kunci: Patient Safety, Pre-Post Partum, Pelayanan Kesehatan

\begin{abstract}
The quality of health services is able to determine the degree of quality on the public health. Yet in fact, problems on low quality of health services stay still which give impacts toward morbidity, disability, even to mortality of patients. This study aims to describe the implementation model of patient safety pre-post partum at $X$ Hospital in Makassar City. Informants are all health workers (midwives, doctors, nurses) involved in the implementation of patient safety pre-post partum. Key informant is the person in charge of pre-post partum implementation at each level of health services. Type of this research is an evaluative research with descriptive approach. This research is located in Makassar City with period of 6 (six) months. Result of the research shows that scoring for the implementation of $X$ Hospital patient safety regarding to the assessment of risk management gains 4,0 (good), while identification and risk management for patient score at 3.7 (good). Reports and incident analysis obtain a value of 3.3 (good enough), the ability to learn and follow through incidents score at 2 (less good), and the implementation of solutions to reduce and minimize the risk receives 3.7 (good). In average, score for all dimensions is 4 (good) with total score of 60 (good enough). In suggestion, the hospital management is expected to improve the implementation of patient safety, especially on the dimensions of learning capability and incident management.
\end{abstract}

Keywords: Patient Safety, Pre-Post Partum, Health Services 
Nurmiati Muchlis, Nasrudin, Tutik Agustini, Samsualam : Patient Safety Pre post Partum....

\section{PENDAHULUAN}

Pencapaian Human Development Indeks (HDI) suatu negara menggambarkan kondisi kualitas kesehatan suatu bangsa. HDI Indonesia pada tahun 2017 menunjukkan peringkat ke-116 (Human Development Report 2017, UNDP). Terdapat beberapa faktor yang dapat mempengaruhi derajat kesehatan masyarakat. Menurut Henrik L. Blum derajat kesehatan masyarakat merupakan masalah kesehatan salah satunya dipengaruhi oleh faktor Pelayanan Kesehatan. Kualitas pelayanan kesehatan dapat menentukan kualitas derajat kesehatan masyarakat. Namun kenyataanyanya, masih terdapat masalah rendahnya kualitas pelayanan yang berdampak pada kesakitan, kecacatan bahkan kematian pasien.

Menurut Healy. J and Dugdale (2009) dalam masa 10 tahun terakhir ini, perhatian dunia terhadap pentingnya peranan keselamatan pasien meningkat terhadap bagaimana strategi serta cara dan kegiatan untuk menciptakan keselamatan bagi pasien di rumah sakit. Beberapa faktor yang mempengaruhi terhadap Kualitas pelayanan kesehatan dan keselamatan pasien adalah faktor organisasi seperti iklim keselamatan dan moral, faktor lingkungan kerja seperti susunan kepegawaian dan dukungan manajerial, faktor tim, seperti kerja tim dan supervisi dan faktor staf (Yuwantina, 2012). Menurut Rusmi (2010) di Indonesia, kasus medical error sulit diidentifikasi. Laporan insiden baru tercatat di Komite Keselamatan Pasien Rumah Sakit (KKPRS) mulai September 2006. Hasil laporan insiden sejak September 2006 sampai Agustus 2007 sebanyak 145 insiden. Kasus medical error identik disebut kejadian gunung es, tidak tampak di dasar tetapi angka kejadian sangat tinggi (Satria W, dkk. 2013).

Kota Makassar merupakan salah kota di wilayah Sulawesi Selatan yang secara kuantitas memiliki sarana pelayanan kesehatan Ibu dan Anak (KIA) yang paling banyak di antara kabupaten/ kota di Sulawesi Selatan. Namun, pertumbuhan sarana pelayanan KIA terbanyak belum diikuti oleh kajian kualitas pelayanan khsusunya pada pelaksanaan patient safety pre-post partum sebagai upaya yang efektif dalam penurunan kasus AKI dan AKB. Pelaksanaan patient safety pre-post partum di Kota Makassar dapat menjadi miniatur pelaksanaan patient safety di Sulawesi Selatan, sehingga penting untuk melakukan kajian 
penerapan patient safety pre-post partum pelayanan kesehatan di rumah sakit Kota Makassar.

Patient safety merupakan sesuatu yang jauh lebih penting daripada sekedar efisiensi pelayanan. Berbagai resiko akibat tindakan medik dapat terjadi sebagai bagian dari pelayanan kepada pasien (Satria, 2013). Patient safety adalah suatu sistem dimana rumah sakit membuat asuhan pasien lebih aman yang meliputi assesment resiko, identifikasi dan pengelolaan hal yang berhubungan dengan resiko pasien, pelaporan dan analisis insiden, kemampuan belajar dari insiden dan tindak lanjutnya serta implementasi solusi untuk meminimalkan timbulnya resiko dan mencegah terjadinya cedera yang disebabkan oleh kesalahan akibat melaksanakan tindakan atau tidak mengambil tindakan yang seharusnya diambil (Bantu, 2014). Menurut WHO (2005), terdapat 5 (lima) tantangan utama pada patient safety yaitu; 1) Blood safety (darah yang aman), 2) Injection practices and immunization (proses injeksi dan imunisasi), 3) Water, basic sanitation (air yang bersih dan aman, serta kebersihan), dan waste management (manajemen sampah), 4) Clinical procedures safety (keamanan prosedur klinis ) serta 5) Hand hygiene (kebersihan tangan).

Keperawatan maternitas terdiri dari periode antenatal-intranatal dan postnatal- bayi baru lahir dan kesehatan reproduksi. Antenatal mulai dari hamil sampai dengan adanya tanda-tanda persalinan (9 bulan). Intranatal mulai dari adanya tanda-tanda persalinan sampai dengan 2 jam setelah plasenta keluar, postnatal: setelah intranatal sampai dengan 40 hari. Pada penelitian ini pre-post partum dibatasi pada tahap intranatal sampai dengan post natal. Postnatal dibatasi pada waktu pasien masih berada dalam tanggung jawab penyelenggara pelayanan kesehatan (masih berstatus pasien pada penyelenggara pelayanan kesehatan) sampai pihak penyelenggara menyatakan ibu bersalin boleh pulang atau pun karena permintaan pulang oleh pasien sendiri.

\section{METODE}

Penelitian ini merupakan penelitian kuantitatif dengan pendekatan deskriptif evaluatif. Data yang digunakan terdiri dari data kualitatif dan kuantitatif. Lokasi penelitian di Rumah Sakit Ibu dan Anak milik swasta di Kota 
Nurmiati Muchlis, Nasrudin, Tutik Agustini, Samsualam : Patient Safety Pre post Partum....

Makassar. Penelitian dilaksanakan selama 6 (enam) bulan. Informan penelitian terdiri dari penanggung jawab pelayanan Ibu dan Anak yang terdiri dari 1 dokter spesialis kandungan, 5 perawat dan 3 bidan. Teknik pengumpulan data menggunakan wawancara mendalam dengan pertanyaan terstruktur. Data kualitatif yang digunakan diperoleh dari hasil wawancara mendalam, sedangkan data kuantitatif diperoleh dari skoring hasil penilaian penerapan patient safety. Analisis data menggunakan content analysis dengan pendekatan evaluatif. Tahapan penelitian ini terbagi menjadi 3 bagian utama, terdiri dari; tahap pertama yaitu tahapan kajian masalah di lapangan berdasarkan data terkait, tahap kedua pengumpulan data dan tahap ketiga analisis data. Penelitian ini didasarkan merujuk pada rencana strategik Menteri Kesehatan Tahun 2015-2019, dan isu strategis penelitian dan pengembangan kesehatan Indonesia.

\section{HASIL}

Berdasarkan hasil penelitian yang dilakukan pada di peroleh hasil penilaian yaitu Assesment risiko merupakan pengumpulan informasi terkait risiko yang dialami ibu hamil pada pre-post partum. Assesment risiko pada tahap input yang dilakukan RS X yaitu terdapat dokumen Standard Operating Procedure (SOP) untuk pelaksanaan assessment risiko. Terdapat form pengisian assessment risiko yang akan dijadikan dasar untuk penentuan tindakan selanjutnya yaitu identifikasi dan manajemen risiko terhadap pasien. SOP digunakan sebagai pedoman pelaksanaan prosedur layanan, merupakan kebijakan resmi dari pihak manajemen rumah sakit. Pada pelaksanaannya, masih menggunakan dokumen secara manual, terdokumentasi secara manual, belum ada link dengan unit lain secara komputerisasi. Nilai yang diperoleh untuk assesment risiko pada tahap input yaitu sebesar 4 (empat). Assesment risiko tahap proses menunjukkan bahwa berdasarkan hasil penelitian yang dilakukan, di RS X penerapan SOP sebagai pedoman pelaksanaan prosedur layanan, merupakan kebijakan resmi dari pihak manajemen rumah sakit. Petugas yang melakukan assesment risiko kompeten. Nilai yang diperoleh untuk assesment risiko tahap proses sebesar 5. Pada assesment risiko tahap output, hasil penelitian menunjukkan bahwa hasil assessment risiko pada pasien dilakukan secara terdokumentasi. Dokumentasi 
dilakukan secara manual. Nilai yang diperoleh untuk assesment risiko tahap output sebesar 3 (tiga).

Identifikasi dan manajemen risiko terhadap pasien merupakan penentuan karakteristik risiko pasien serta upaya solusi dalam penanganan risikonya. Pada tahap input yaitu kebijakan sudah tersedia dan di laksanakan oleh tenaga kompeten namun, pelaksanaan masih manual. Identifikasi pasien pre-post partum menggunakan gelang tanda pengenal berdasarkan warna. Terdapat pengkategorian jenis pasien berdasarkan tingkat risikonya, tanda yang digunakan berupa pemberian gelang kepada pasien. Tingkat risiko didasarkan pada warna gelang yang diberikan kepada pasien. Warna merah jambu digunakan untuk pasien baru masuk, merah untuk pasien alergi. Ungu untuk penolakan tindakan, kuning untuk risiko jatuh. Bahan atau peralatan yang digunakan berdasarkan SOP dan aplikasinya sebagian memperhatikan penggunaan Alat Pelindung Diri (APD) pada saat tindakan persalinan. Nilai yang diperoleh untuk identifikasi dan manajemen risiko tahap input adalah 4 (empat). Pada tahap proses yaitu kebijakan sudah tersedia dan di laksanakan oleh tenaga kompeten, namun pelaksanaan masih manual. Identifikasi pasien pre-post partum, nilai yang diperoleh yaitu 3 (tiga). Pada tahap output yaitu tersedia dokumen atau bukti hasil kegiatan secara sistematis. Terdapat rekam dan dilakukan oleh petugas yang kompeten. Data didokumentasi dan disosialisasikan secara manual. Nilai yang diperoleh untuk identifikasi dan manajemen risiko tahap output yaitu sebesar 4 (empat).

Pelaporan dan analisis insiden merupakan bentuk pengumpulan informasi beserta jalur informasi dan penjabaran insiden pada pre-post partum. Pada tahap input yaitu di rumah sakit sudah terdapat SOP. Terdapat format pengisian untuk insiden. Terdapat Tim IPCN yang bertugas melakukan evalauasi kinerja. Nilai yang diperoleh utuk pelaporan dan analisis insiden tahap input yaitu sebesar 4 (empat). Pada tahap proses yaitu bentuk pengumpulan informasi masih di lakukan secara manual oleh tenaga kompeten. Upaya evaluasi oleh tim IPCN. Nilai yang diperoleh untuk pelaporan dan analisis tahap proses sebesar 3 (tiga). Pada tahap output yaitu terdapat laporan kejadian insiden. Terdapat laporan IPCN, dan 
pelaporan bersifat manual. Nilai yang diperoleh untuk pelaporan dan analisis insiden tahap output sebesar 3 (tiga).

Kemampuan untuk belajar dan menindaklanjuti insiden merupakan upaya lesson learn dari pihak penyelenggara pelayanan kesehatan atas segala insiden terkait pre-post partum pasien, serta upaya tindaklanjutnya. Pada tahap input yaitu belum ada SOP terkait dengan pelaporan secara insiden secara tertulis untuk pasien post partum. Nilai yang diperoleh yaitu 1 (satu). Pada tahap proses yaitu di rumah sakit terdapat kegiatan kemampuan untuk belajar dan menindaklanjuti insiden tahap proses, namun belum menggunakan SOP (dilakukan secara alami). Nilai yang diperoleh untuk tahap ini yaitu 2 (dua). Pada tahap output yaitu tersedia dokumen hasil kegiatan kemampuan untuk belajar dan menindaklanjuti insiden tahap output, namun dilakukan secara manual. Nilai yang diperoleh yaitu 3 (tiga).

Pada tahap input yaitu menerapkan solusi untuk mengurangi serta meminimalisir risiko. Upaya yang dilakukan rumah sakit yaitu terdapat SOP. Dokumen yang ada di rumah sakit sudah menjadi dokumen resmi rumah sakit. Nilai yang diperoleh yaitu 4 (empat). Pada tahap proses yaitu memberikan tanda pengenal pada pasien baru masuk baik pasien pre-post partum. Di rumah sakit terdapat SOP. Nilai yang diperoleh yaitu 4 (empat). Pada tahap output yaitu penyediaan laporan hasil kegiatan. Dokumentasi masih secara manual dan dilakukan oleh tenaga kompeten. Nilai yang diperoleh yaitu 3 (tiga). Berikut merupakan tabel yang menggambarkan kesimpulan nilai dari seluruh skoring penerapan patient safety pre-post partum di RS X.

Tabel 1. Hasil Skoring Penerapan Patient Safety pada RS X di Kota Makassar

\begin{tabular}{llccccc}
\hline No. & \multicolumn{1}{c}{$\begin{array}{c}\text { Penerapan } \\
\text { patient safety }\end{array}$} & Input & Proses & Output & Rata-rata & Total \\
\hline 1. & $\begin{array}{l}\text { Assesment risiko } \\
\text { Identifikasi dan }\end{array}$ & 4 & 5 & 3 & 4 & 12 \\
& $\begin{array}{l}\text { manajemen risiko } \\
\text { terhadap pasien }\end{array}$ & 3 & 4 & 3,7 & 11 \\
3. $\quad \begin{array}{l}\text { Pelaporan dan analisis } \\
\text { insiden }\end{array}$ & 4 & 3 & 3 & 3,3 & 10 \\
4. & 1 & 2 & 3 & 2 & 6 \\
\hline $\begin{array}{l}\text { Kemampuan untuk } \\
\text { belajar dan } \\
\text { menindaklanjuti }\end{array}$ & & & & & \\
\hline
\end{tabular}




\begin{tabular}{llccccc}
\hline No. & $\begin{array}{c}\text { Penerapan } \\
\text { patient safety }\end{array}$ & Input & Proses & Output & Rata-rata & Total \\
\hline 5. & $\begin{array}{l}\text { insiden } \\
\begin{array}{l}\text { Menerapkan solusi } \\
\text { untuk mengurangi dan } \\
\text { meminimalisir risiko }\end{array}\end{array}$ & 4 & 4 & 3 & 3,7 & 11 \\
\hline & Jumlah & & & 50 \\
\hline
\end{tabular}

Keterangan : Nilai minimal yang mungkin diperoleh: 3. Nilai maksimal yang dapat dicapai: 75 (ada 5 indikator, maksimal nilai pencapaian tiap indikator : 15).

\section{PEMBAHASAN}

Hasil penelitian menunjukkan bahwa masih ada beberapa item pelaksanaan patient safety di pelayanan KIA yang belum dilaksanakan secara optimal. Kemampuan untuk belajar dan menindaklanjuti insiden merupakan tahapan pelaksanaan prosedur patient safety yang mendapatkan nilai rata-rata terendah yaitu sebanyak 2 (dua), khususnya pada nilai tahap input. Assesment risiko merupakan tahapan prosedur patient safety yang memiliki rata-rata nilai tertinggi, yaitu 4 (empat). Pada tahap awal prosedur patient safety di pelayanan kesehatan tersebut dilaksanakan secara baik, namun pada tingkatan selanjutnya mengalami beberapa penurunan nilai. Penelitian lain menjelaskan bahwa tahapan assesment risiko mengidentifikasi, menilai, serta menyusun prioritas risiko secara proaktif yang bertujuan untuk menghilangkan atau meminimalkan dampaknya (JCAHO). Komite Keselamatan Pasien Rumah Sakit (KKPRS) dan dari Joiny Commission International (JCI) menyatakan bahwa program manajemen risiko digunakan untuk identifikasi risiko dalam rangka mengurangi angka Kejadian Tidak Diharapkan (KTD) serta risiko lain yang mengancam keselamatan pasien dan staf sehingga dapat meningkatkan mutu pelayanan dan keselamatan pasien (JCI, 2017; KKPRS, 2015).

Berdasarkan hasil penelitian tahap asssesment risiko diketahui bahwa RS X telah memenuhi syarat mutu keselamatan pasien. Terdapat dokumen SOP sebagai pedoman pelaksanaan prosedur layanan dan memiliki petugas untuk pelaksanaan assesment resiko namun masih di laksanakan secara manual. Hal ini didukung oleh penelitian (Susilo \& Kaho, 2011) yang menjelaskan bahwa manajemen risiko merupakan sebuah wujud penerapan prinsip dari good corporate 
Nurmiati Muchlis, Nasrudin, Tutik Agustini, Samsualam : Patient Safety Pre post Partum....

governance yang apabila program manajemen risiko ini terlaksana maka akan berkontribusi pada keselamatan pasien. Penelitian lain menjelaskan bahwa apabila assessment risiko jatuh tidak di jalankan maka petugas tidak dapat melakukan intervensi pencegahan risiko dan hal ini dapat mengakibatkan terjadinya insiden jatuh pasien di rumah sakit (Nur, Dharmana, \& Santoso, 2017).

Selanjutnya merupakan tahap kemampuan untuk belajar dan menindaklanjuti insiden. Hasil penelitian menjelaskan bahwa nilai rata-rata terendah terjadi karena belum adanya SOP dengan pelaporan insiden secara tertulis, sehingga petugas rumah sakit menindaklanjuti sebuah insiden secara alami tanpa adanya pemahaman dan pelatihan yang memadai serta prosedur yang telah terverifikasi. Penelitian ini sejalan dengan (Djatnika, Arso, \& Jati, 2018) yang menyatakan bahwa perlakuan risiko masih belum berhasil menurunkan tingkat kegawatan beberapa risiko dikarenakan kompleksitas dari rencana perlakuan tersebut. Tidak adanya sistem evaluasi yang tepat akan menjadi salah satu penghambat untuk meningkatkan kemampuan yang ada (Napirah, Muhammad, \& dkk, 2017). Fondasi yang digunakan dalam implementasi program keselamatan pasien adalah membangun kultur keselamatan pasien (culture of safety) yang disokong dengan tiga pilar yaitu aspek teknologi, prosedur dan Sumber Daya Manusia (SDM) (Cahyono, 2008). Oleh karena itu pentingnya peran manajemen dalam menetapkan suatu kebijakan yang dalam hal ini pembuatan SOP untuk keselamatan pasien. Berdasarkan penelitian (Cahyawening, Intiasari, \& Aji, 2018) menyatakan bahwa dari peran kebijakan program tentang keselamatan pasien yang telah di implementasikan telah memberikan manfaat yang dirasakan oleh tenaga kesehatan. Manfaat tersebut perubahan pada perilaku dan lebih confident dalam bekerja, serta terhindar dari kecelakaan kerja, penyakit akibat kerja dan kejadian yang tidak diinginkan lainnya.

Penelitian ini sejalan dengan penelitian (Toemandoek, Kristanto, \& Lumunon, 2016) yang menjelaskan bahwa terdapat hubungan antara pemahaman perawat pelaksana, pemahaman mengenai prinsip keselamatan pasien, pemahaman mengenai manajemen keselamatan pasien dan pemahaman mengenai penerapan keselamatan pasien dalam pelayanan keperawatan dengan budaya 
keselamatan pasien oleh perawat di Ruang Rawat Inap Obstetri Dan Ginekologi Rumah Sakit Umum Pusat Prof. DR. R.D. Kandou Manado. Penelitian yang sejalan juga di sampaikan oleh (Neri, Lestari, \& Yetti, 2018) yang menyatakan bahwa kebijakan dan SPO di Rumah Sakit Umum Padang Pariaman sudah lengkap.

Tahapan identifikasi dan manajemen risiko serta penerapan solusi untuk mengurangi dan meminimalisir risiko mendapatkan nilai rata-rata yang sama yaitu 3,7. Hal ini menunjukkan bahwa dengan menerapkan kebijakan penggunaan gelang tanda pengenal berdasarkan warna, pengkategorian jenis pasien berdasarkan tingkat risikonya, penggunaan APD (Alat Pelindung Diri) pada saat tindakan persalinan yang dilaksanakan secara sistematis maka akan mempermudah proses pelayanan kesehatan dan mengurangi risiko yang akan terjadi. Hal ini sejalan dengan peraturan (Kementerian kesehatan RI, 2011) yaitu untuk mengidentifikasi seorang pasien yang harus diperlukan adalah nama pasien, nomor rekam medis, tanggal lahir, gelang identitas pasien dengan bar-code, dan lain-lain. Penerapan patient safety di RS X secara keseluruhan masih dilakukan secara manual. Dimana pada tahap output mendapatkan nilai rata-rata terendah yaitu 3,2. Di negara berkembang pelaporan hasil kegiatan telah banyak menggunakan komputerisasi yang berbasis sistem infomasi. Pengolahan data menggunakan program komputer dapat mengurangi tingkat kesalahan yang ada dan dapat diolah lebih lanjut sehingga mengurangi kesalahan dalam pelaporan insiden keselamatan pasien (Tristantia, 2018). Sejalan dengan itu, (Handayanti \& al, 2013) berpendapat bahwa dengan adanya teknologi akan sangat membantu dalam meningkatkan keuntungan bagi organisasi. Beberapa penelitian lainnya juga menjelaskan bahwa patient safety merupakan kegiatan yang terintegrasi.

\section{SIMPULAN}

Prosedur patient safety di pelayanan kesehatan tersebut dilaksanakan secara baik, namun pada tingkatan selanjutnya, ada beberapa hal yang belum berjalan dengan baik. Kemampuan untuk belajar dan menindaklanjuti insiden merupakan tahapan pelaksanaan prosedur patient safety yang mendapatkan nilai rata-rata terendah. Tidak adanya SOP dalam menindaklanjuti insiden menjadi kendala 
Nurmiati Muchlis, Nasrudin, Tutik Agustini, Samsualam : Patient Safety Pre post Partum....

dalam melaksanakan pelayanan kesehatan. Hal ini merupakan tanggung jawab dari seluruh pihak yang terlibat agar penerapan upaya keselamatan pasien dapat berjalan dengan baik dan mencapai tujuan yang diinginkan.

\section{UCAPAN TERIMA KASIH}

Terima kasih kepada Ristekdikti yang telah memberikan dukungan pendanaan pada pelaksanaan penelitian ini.

\section{DAFTAR PUSTAKA}

Cahyawening, P. T., Intiasari, A. D., \& Aji, B. (2018). Implementasi Clinical Risk Management (CRM) di Unit Gawat Darurat RSUD Banyumas. Journal Kesmas Indonesia, Vol 10, No 2.

Cahyono, J. S. (2008). Membangun Budaya Keselamatan Pasien Dalam Praktik Kedokteran. Yogyakarta: Kanisius.

Djatnika, K. M., Arso, S. P., \& Jati, S. P. (2018). Analisis Pelaksanaan Manajemen Risiko di Instalasi Farmasi Rumah Sakit Umum Daerah Tugurejo Semarang. Jurnal Kesehatan Masyarakat (e-journal) , Vol 7, No 1.

Handayanti, T., \& al, e. (2013). Evaluasi Pelaksanaan Sistem Pelaporan Rekam Medis di Klinik Asri Medical Center. Jurnal Manajemen Informasi Kesehatan Indonesia .

JCI. (2017). Joint Commission International Accreditation Standards for Hospital 6th Edition.

Kementerian kesehatan RI. (2011). Standar Akreditasi Rumah Sakit. Jakarta: Dirjen Bina Pelayanan Medik.

KKPRS. (2015). Pedoman Pelaporan Inseiden Keselamatan Pasien (IKP) (Patient Safety Incident Reoort). Jakarta: Komite Keselamatan Pasien Rumah Sakit.

Napirah, Muhammad, R., \& dkk. (2017). Penialian Kinerja dengan Menggunakan Konsep Performance Prism di Unit Rawat Jalan RSUD Undata Palu. Jurnal Preventif, Vol 8, No 1, 1-58.

Neri, R. A., Lestari, Y., \& Yetti, H. (2018). Analisis Pelaksanaan Sasaran Keselamatan Pasien Di Rawat Inap Rumah Sakit Umum Daerah Padang Pariaman. Jurnal Kesehatan Andalas .

Nur, H. A., Dharmana, E., \& Santoso, A. (2017). Pelaksanaan Asesmen Risiko Jatuh di Rumah Sakit. Indonesian Journal of Nursing and Midwifery, Vol 5, No 2, 123-133.

Pomey M-P, Contandriopoulos A-P, François P, Bertrand D. Accreditation: a tool for organizational change in hospitals? Int J Health Care Qual Assur. 2004;17(3):113-124.

Ratna, N., Suhartono, dan Sri W, 2012. Infeksi Nosokomial di RSUD Setjonegoro Kabupaten Wonosobo. Media Kesehatan Masyarakat Indonesia, Vol.11.No.1, 94-100.

Smith, J., 1998. The book, The publishing company. London, $2^{\text {nd }}$ edition 
Susilo, L., \& Kaho, V. R. (2011). Manajemen Risiko berbasis ISO 31000 untuk Industri Nonperbankan. Jakarta: PPM.

Toemandoek, M. R., Kristanto, E., \& Lumunon, T. (2016). Faktor-faktor yang Berhubungan dengan Penerapan Sasaran Keselamatan Pasien (Patient Safety) pada Perawat di Ruang Rawat Inap Obstetri dan Ginekologi Rumah Sakit Umum Pusat Prof. DR. R.D. Kandou Manado.

Tristantia, A. D. (2018). Evaluasi Sistem Pelaporan Insiden Keselamatan Pasien Di Rumah Sakit. Jurnal Administrasi Kesehatan Indonesia, Vol 6, No 2. 